\title{
Comparative assessment the subsidized housing using LEED, BREEAM and Greenship Neigborhood (Case study: Parung Panjang, West Java, Indonesia)
}

\author{
Andrean Eka Lucianto $^{1}$, Hayati Sari Hasibuan ${ }^{1 *}$, and Herdis Herdiansyah ${ }^{1}$ \\ ${ }^{1}$ School of Environmental Science, Universitas Indonesia, Jakarta, 10430, Indonesia.
}

\begin{abstract}
Indonesia as a country with a large population has challenges in being able to provide housing that applies a sustainable concept but still has to be affordable for the community. Therefore, this research aims to compare the implementation of the three pillars of sustainability from several Neighborhood Sustainability Assessment. The method used in this research is a comparative analysis in assessing the concept of sustainable in subsidized housing and descriptive analysis to provide suggestions for improving the sustainable application in subsidized housing. The assessment carried out by the researchers using direct observation, masterplan interpretation and satellite photo interpretation. The results of the assessment using the Neighborhood Sustainability Assessment of several countries on subsidized housing for Perumnas Parung Panjang obtained silver level from LEED, pass level from BREEAM and bronze level from Greenship. On the other hand, from the aspect of the three pillars of sustainability, it is known that the economic pillars (36.27\%) and the environmental pillars $(32.14 \%)$ have a lower percentage of variable fulfilment compared to the social pillars $(61.59 \%)$, so that several corrective steps are needed to maximize the application of the concept of sustainable and obtained a better NSA assessment score.
\end{abstract}

\section{Introduction}

The total population of Indonesia which reached 271.07 million in mid-2020, with the average percentage of population in urban areas in Indonesia of 56.7 [3,4]. The large number of human populations living in urban areas creates problems in the context of urban development, including a significant increase in energy consumption, an increase in waste and waste generation, and a reduction in the historical value of the area and local cultural heritage [2]. Therefore, attention to the development of environmentally friendly urban areas should receive higher attention to create a balance between the natural environment, the social environment and the built environment [2].

The sustainable housing index that has been published in Indonesia is the Green Neighborhood published by the Green Building Council Indonesia (GBCI). The Green

* Corresponding author: hayati.hasibuan@ui.ac.id 
Neighborhood Index (GNI) aims to classify the level of sustainability of an area as a green area [6]. Beside that, the number of housing developments in Indonesia is as follows: $69 \%$ is subsidized housing construction and $31 \%$ is non-subsidized housing construction. From this data, it is known that, the number of subsidized housing construction is greater than 2 times that of the non-subsidized housing construction. Thus, the construction of subsidized housing should also be given greater attention, because more Indonesians need it and later live in subsidized housing areas. A subsidized housing area which is generally built on a fairly large scale, should give attention to the concept of sustainability in it.

In every subsidized housing development, the factor of affordability of the selling price of a house is the main focus, where the level of the selling price must be equal to the purchasing power of the housing market, especially for low-income/low-income communities [8]. On the government policy side, the selling price of subsidized houses has been set by the Ministry of Public Works and Public Housing in the Decree of the Minister of Public Works and Public Housing Number 535/KPTS/M/2019 concerning Limits on Selling Price of Houses that are obtained through Financing Subsidized Home Ownership. This causes affordable housing to be defined as a house that is small in size, uses affordable materials, and is built in an area with cheap land prices in the city perimeter $[10,11]$.

In developing countries, it is seen that Sustainable Housing is a development that is far from affordable / unaffordable for the middle to lower income community, so that efforts to synergize between Sustainability and Affordable Housing are the main challenges in developing countries, with the level of application of the principle of sustainability in subsidized housing which is still at the stage very low [9]. The application of the concept of sustainability to subsidized housing is indeed a major challenge and problem. Environmental, social and economic pillars must consider in a balanced manner to achieve sustainability in the subsidized housing area. The purpose of this research is to compare the implementation of the three pillars of sustainability from several NSAs, so that they can provide a more comprehensive input on improvements to the subsidized housing. This research will focus on assessing the planning design in implementing the Green Neighborhood index on subsidized housing, a comparison of several Green Neighborhood indexes from several countries, namely LEED from the United States, BREEAM from the UK and Greenship from Indonesia with a case study of subsidized housing built by Perumnas in Parung area. Panjang, West Java, Indonesia.

This research is a case study in the subsidized housing of Perumnas Parung Panjang. Perumnas Parung Panjang is a subsidized housing with a total number of occupancy of 10,474 units and obtaining subsidized financing from the government in the form of a Housing Ownership Credit (KPR) ceiling from the bank as a partner providing the Housing Financing Liquidity Facility (FLPP).

\section{Method}

\subsection{Study area}

This research will be carried out with a case study in the subsidized housing of Perumnas Parung Panjang which is located at coordinates lat $6^{\circ} 21^{\prime} 13.9^{\prime \prime} \mathrm{S}$ and long $106^{\circ} 34^{\prime} 1.5^{\prime \prime} \mathrm{E}$. The subsidized housing area covering \pm 214 hectares. Perumnas Parung Panjang has developed 4 sectors and the sector 5 , which is still in the development stage, so the suggestions from this research used as improvements in the sector that developing.

\subsection{Data Collection}


The data used are primary data from direct observation and secondary data from satellite photos and master plan images of subsidized housing areas. Details of the secondary data sources can be seen in Table 1 .

Table 1. Detail data and the source of the data.

\begin{tabular}{|c|c|}
\hline Data & Source \\
\hline Observation data & Direct observation, 2020 \\
\hline Drone photos & Drone acquisition by researcher, 2020 \\
\hline Master plan area & Perumnas (National Housing and Urban Development Company), 2020 \\
\hline
\end{tabular}

\subsection{Comparative Assessment Analysis}

The method used in this study is a comparative analysis using the Green Neighborhood index of several countries to measure the level of implementation of the concept of sustainability, namely: LEED, BREEAM and Greenship [7]. The assessment carried out by the researchers using direct observation, master plan interpretation and remote observation with satellite photo interpretation. The results of the observations used for the assessment according to the indicator points in each index. Point assessment given by matching conditions and data from the field and interpretation with indicators in each NSA. Then a descriptive analysis carried out to identify improvement steps that applied to the case study locations so that the implementation of the concept of sustainability is better. Descriptive analysis is carried out based on indicators that have the least assessment points, then indicators that have the least impact on price increases are sorted, because subsidized housing is intended for low-income people who are sensitive to the selling price of houses.

\section{Results and discussion}

\subsection{The results of the LEED assessment}

LEED-ND (Leadership in Energy and Environmental Design) is an index created by the United States Green Building Council (USGBC) in the United States in 2009 then updated in 2018. LEED-ND aims to inspire and help create more regional development. sustainable, has good connectivity and builds an area that meets the needs of the community in it [13].

Table 2. The results of the LEED assessment.

\begin{tabular}{|c|c|c|c|}
\hline No. & Variabel & Max Score & $\begin{array}{c}\text { Assessment } \\
\text { Score }\end{array}$ \\
\hline 1. & Smart Location and Linkage & 27 & 11 \\
\hline 2. & $\begin{array}{c}\text { Neighborhood Pattern and } \\
\text { Design }\end{array}$ & 44 & 32 \\
\hline 3. & $\begin{array}{c}\text { Green Infrastructure and } \\
\text { Buildings }\end{array}$ & 29 & 2 \\
\hline 4. & Innovation & 6 & 2 \\
\hline
\end{tabular}




\begin{tabular}{|c|c|c|c|}
\hline 5. & Regional Priority & 4 & 3 \\
\hline Total & 110 & 50 \\
\hline
\end{tabular}

LEED area certification is provided through independent third party verification the construction site and design meet the high level criteria of environmentally responsible and sustainable development. The latest LEED-ND index in 2018 has several variables, namely Smart Location and Linkage (SLL), Neighborhood Pattern and Design (NPD), Green Infrastructure and Buildings (GIB), Innovation (IN) and Regional Priority (RP) [12]. The results of the assessment of the level of application of the sustainable concept using the LEED index can be seen in Table 2 .

\subsection{The results of the BREEAM assessment}

BREEAM (Building Research Establishment's Environmental Assessment Method) for Community is an index created by BRE Global Ltd in the United Kingdom in 2008 then updated in 2012. BREEAM (Community) aims to ensure the availability of social and economic pillar standards in a regional development project, with hope to mitigate the impact that may occur due to these developments. BREEAM (Community) would be better applied in medium or wide areas of mixed-use development, but can also be applied to regional development units [13]. BREEAM is the earliest applied method in the world to assess, rank and certify the sustainability of buildings and areas. BREEAM is used in more than 550,000 buildings and more than 2 million are registered for certification in more than 50 countries around the world. BREEAM also has a tool that focuses on environmental development. The BREEAM for Community Index has a total of 118 points which are divided into several variables, namely Governance, Social and Economic Welbeing, Resource and Energy, Land Use and Ecology, and Transport and Movement [5]. The results of the assessment of the level of application of the sustainable concept using the BREEAM index can be seen in Table 3 .

Table 3. The results of the BREEAM assessment.

\begin{tabular}{|c|c|c|c|}
\hline No. & Variabel & Max Score & $\begin{array}{c}\text { Assessment } \\
\text { Score }\end{array}$ \\
\hline 1. & Governance & 8 & 5 \\
\hline 2. & Social and economic wellbeing & 47 & 17 \\
\hline 3. & Resources and energy & 31 & 3 \\
\hline 4. & Land Use and ecology & 18 & 8 \\
\hline 5. & Transport and movement & 14 & 12 \\
\hline & Total & 118 & 45 \\
\hline
\end{tabular}

\subsection{The results of the Greenship assessment}

Greenship - Green Neighborhood (GN) is an index created by GBCI in the Indonesia in 2015. Greenship GN aims to spread and inspire in the implementation and realization of a sustainable area In addition, the benefits of applying the Greenship GN index are as follows 
to maintain harmony and balance of environmental ecosystems, and to improve the environmental quality of a healthy area; in order to minimize the impact of development on the environment; in order to improve the quality of the micro climate; in order to apply the principles of connectivity, safety and comfort on pedestrian paths; and to maintain a balance between demand and availability of resources in the future [6]. The Greenship - GN Index has several variables, namely Land Ecological Enhancement, Movement and Connectivity, Water Management and Conservation, Solid Waste and Materials, Community Wellbeing Strategy, Building and Energy, Innovation and Future Development. The results of the assessment of the level of application of the sustainable concept using the Greenship index can be seen in Table 4 [1].

Table 4. The results of the Greenship assessment.

\begin{tabular}{|c|c|c|c|}
\hline No. & Variabel & Max Score & $\begin{array}{c}\text { Assessment } \\
\text { Score }\end{array}$ \\
\hline 1. & Land Ecological Enhancement & 19 & 8 \\
\hline 2. & Movement and Connectivity & 26 & 12 \\
\hline 3. & $\begin{array}{c}\text { Water Management and } \\
\text { Conservation }\end{array}$ & 18 & 2 \\
\hline 4. & Solid Waste and Material & 14 & 6 \\
\hline 5. & Community Wellbeing Strategy & 16 & 8 \\
\hline 6. & $\begin{array}{c}\text { Building and Energy } \\
\text { Development }\end{array}$ & 18 & 3 \\
\hline 7. & \begin{tabular}{c} 
Tnnovation and Future \\
\hline
\end{tabular} & 122 & 43 \\
\hline
\end{tabular}

\subsection{Comparative assessment of subsidized housing between the Neighborhood Sustainable Assessment (NSA)}

The environmental sustainability assessment system does not cover or does not pay enough attention to certain areas of the three pillars of sustainable development, the environmental pillar has more indicators and the number of points weighted than the economic and social pillars [2]. The NSA index which has the most balanced indicator of the pillars of sustainability is BREEAM compared to LEED and Greenship [2, 7]. In addition, there are weaknesses in LEED and Greenship, namely the existence of several indicators that allow the occurrence of bulk of possible points by only fulfilling the very weighty indicators. The advantage of BREEAM is that it applies weights to multilevel indicator categories which helps to overcome these problems [3].

Table 5. The results of the Greenship assessment.

\begin{tabular}{|c|c|c|c|}
\hline No. & $\begin{array}{c}\text { Neighborhood Sustainable } \\
\text { Assessment }\end{array}$ & $\begin{array}{c}\text { Assessment } \\
\text { Score }\end{array}$ & $\begin{array}{c}\text { Assessment } \\
\text { Level }\end{array}$ \\
\hline 1. & LEED & 50 & Silver Level \\
\hline 2. & BREEAM & 45 & Pass Level \\
\hline
\end{tabular}




\begin{tabular}{|l|l|l|l|}
\hline 3. & Greenship & 43 & Bronze Level \\
\hline
\end{tabular}

The results of the LEED, BREEAM and Greenship assessments in Table 5, it knows that the implementation of the sustainable concept in Perumnas Parung Panjang housing is still not optimal.

Table 6. The comparative analysis between these score of variables.

\begin{tabular}{|c|c|c|c|c|c|c|}
\hline $\begin{array}{c}\text { Pillar of } \\
\text { sustainable }\end{array}$ & $\begin{array}{l}\text { Variable of } \\
\text { LEED }\end{array}$ & $\begin{array}{l}\text { Score } \\
\text { (SoS) } \\
\text { LEED } \\
\end{array}$ & $\begin{array}{l}\text { Variable of } \\
\text { BREEAM }\end{array}$ & $\begin{array}{c}\text { Score } \\
\text { (SoS) } \\
\text { BREEAM } \\
\end{array}$ & $\begin{array}{l}\text { Variable of } \\
\text { Greenship }\end{array}$ & $\begin{array}{c}\text { Score } \\
\text { (SoS) } \\
\text { Greenship }\end{array}$ \\
\hline \multirow{5}{*}{$\begin{array}{l}\text { Environ- } \\
\text { ment }\end{array}$} & $\begin{array}{l}\text { Smart Location } \\
\text { and Linkage } \\
\text { (11) }\end{array}$ & \multirow{5}{*}{18} & $\begin{array}{c}\text { Resources and } \\
\text { energy (3) }\end{array}$ & \multirow{5}{*}{23} & $\begin{array}{l}\text { Land Ecological } \\
\text { Enhancement } \\
(8)\end{array}$ & \multirow{5}{*}{31} \\
\hline & $\begin{array}{c}\text { Green } \\
\text { Infrastructure } \\
\text { and Buildings } \\
\text { (2) }\end{array}$ & & \multirow{2}{*}{$\begin{array}{l}\text { Land Use and } \\
\text { ecology (8) }\end{array}$} & & $\begin{array}{c}\text { Movement and } \\
\text { Connectivity } \\
\text { (12) }\end{array}$ & \\
\hline & Innovation (2) & & & & $\begin{array}{c}\text { Water } \\
\text { Management } \\
\text { and } \\
\text { Conservation (2) }\end{array}$ & \\
\hline & \multirow{2}{*}{$\begin{array}{l}\text { Regional } \\
\text { Priority (3) }\end{array}$} & & \multirow{2}{*}{$\begin{array}{c}\text { Transport and } \\
\text { movement (12) }\end{array}$} & & $\begin{array}{l}\text { Solid Waste and } \\
\text { Material (6) }\end{array}$ & \\
\hline & & & & & $\begin{array}{c}\text { Building and } \\
\text { Energy (3) }\end{array}$ & \\
\hline Social & $\begin{array}{c}\text { Neighborhood } \\
\text { Pattern and } \\
\text { Design (32) } \\
\end{array}$ & 32 & Governance (5) & 5 & $\begin{array}{l}\text { Community } \\
\text { Wellbeing } \\
\text { Strategy (8) }\end{array}$ & 8 \\
\hline Economic & - & & $\begin{array}{c}\text { Social and } \\
\text { economic } \\
\text { wellbeing (17) }\end{array}$ & 17 & $\begin{array}{l}\text { Innovation and } \\
\text { Future } \\
\text { Development (4) }\end{array}$ & 4 \\
\hline
\end{tabular}

The results of the comparison of the scores of each NSA show that the three pillars of the concept of sustainability have unbalanced weight values. Furthermore, it calculated the percentage weighted value $(\% \mathrm{SoS})$ of each pillar of sustainability $(\mathrm{SoS})$ to the total maximum value $(\mathrm{Mv})$ in equation 1.

$$
\% \mathrm{SoS}=\frac{\operatorname{SoS}}{M v} \times 100 \%
$$

Table 7. The sustainable application percentage of NSA.

\begin{tabular}{|c|c|c|c|c|c|}
\hline No. & $\begin{array}{c}\text { Pillar of } \\
\text { sustainable }\end{array}$ & LEED & BREEAM & Greenship & Average \\
\hline 1. & Environmental & $27.27 \%$ & $36.51 \%$ & $32.63 \%$ & $32.14 \%$ \\
\hline 2. & Social & $72.27 \%$ & $62.50 \%$ & $50 \%$ & $61.59 \%$ \\
\hline 3. & Economic & - & $36.17 \%$ & $36.36 \%$ & $36.27 \%$ \\
\hline
\end{tabular}

Comparative assessment of subsidized housing with the variables LEED, BREEAM and Greenship is associated with the three pillars of the concept of sustainability, namely: environmental, social and economic, so it will be obtained the strongest and weakest pillars 
in the application in the subsidized housing area of Perumnas Parung Panjang. The results of the comparative analysis between these score of variables can be seen in Table 6 and the percentage of sustainable application between assessment score with maximum score on each three pillars can be seen in Tabel $7[5,6,12]$.

To be able to maximize the assessment score of the implementation of the sustainable concept, Perumnas Parung Panjang requires several improvement steps in the subsidized housing area. On the other hand, subsidized housing must still consider affordability for lowincome people, so the solution, so the solutions offered is very price sensitive.

Table 8. The improvement of subsidized housing according to the variables in each NSA.

\begin{tabular}{|c|c|c|c|}
\hline $\begin{array}{c}\text { Pillar of } \\
\text { sustainable }\end{array}$ & LEED & BREEAM & Greenship \\
\hline Environmental & $\begin{array}{c}\text { Building energy } \\
\text { efficiency (2), } \\
\text { Building water } \\
\text { efficiency (1), Water } \\
\text { efficiency landscaping } \\
\text { (1), Existing building } \\
\text { reuse (1), } \\
\text { Infrastructure energy } \\
\text { efficiency (1), Recycle } \\
\text { content in } \\
\text { Infrastructure (1). }\end{array}$ & $\begin{array}{l}\text { Low impact materials } \\
\text { (6), Resources } \\
\text { efficiency (4), Ecology } \\
\text { strategy (1), } \\
\text { Enhancement of } \\
\text { ecological value (3). }\end{array}$ & $\begin{array}{c}\text { preserves native plants } \\
\text { (2), urban farming local } \\
\text { vegetable and fruit (2), } \\
\text { avoid on street parking } \\
\text { (1), protecting top soil } \\
\text { (1), Local material (2), } \\
\text { Reuse road materials } \\
\text { (2) }\end{array}$ \\
\hline Social & $\begin{array}{l}\text { Reduce parking } \\
\text { footprint (1), } \\
\text { Transportation } \\
\text { demand management } \\
\text { (2), Local food } \\
\text { production (1). }\end{array}$ & $\begin{array}{c}\text { Community } \\
\text { management of } \\
\text { facilities (3), Training } \\
\text { and skills (3), } \\
\text { Demographic needs and } \\
\text { priorities (1), Inclusive } \\
\text { design (3). }\end{array}$ & $\begin{array}{l}\text { Promote the sustainable } \\
\text { lifestyles (1), } \\
\text { Sustainable living } \\
\text { socialization program } \\
\text { (3), Local cultural } \\
\text { preservation activities } \\
\text { (4), Simulation of } \\
\text { disaster response (2) }\end{array}$ \\
\hline Economy & - & Economic impact (2). & $\begin{array}{l}\text { Cost efficiency } \\
\text { innovation (2) }\end{array}$ \\
\hline $\begin{array}{c}\text { Total of } \\
\text { improvement } \\
\text { score }\end{array}$ & $50+11=61$ & $45+26=71$ & $43+21=64$ \\
\hline $\begin{array}{c}\text { Level of } \\
\text { improvement } \\
\text { score }\end{array}$ & Gold Level & Very Good & Gold \\
\hline
\end{tabular}

Stakeholders, such as the government, developers and estate management can take corrective steps according to the variables in the NSA. Several steps to improve the implementation of the concept of sustainability in subsidized housing are linked to the variables in the NSA and the projection of scores that can be obtained by the subsidized housing of Perumnas Parung Panjang can be seen in Table 8 [5, 6, 12].

\section{Conclusion}

The results of the assessment of subsidized housing at Perumnas Parung Panjang show that the environmental pillar (32.14\%) and the economic pillar (36.27\%) have lower variable fulfillment process compared to the social pillar (61.59\%). Subsidized housing is a necessity for most people in developing countries, such as Indonesia, so that it requires greater attention in creating subsidized housing areas that fulfill the concept of sustainability. Therefore, 
several steps are needed to improve, so that the implementation of the concept of sustainability can be maximally implemented and obtain a better NSA assessment score. Suggestions for further research are the steps to improve contained in this research can be followed by a further feasibility study.

\section{Acknowledgement}

Thanks are addressed to the Parung Panjang and Cibunar Village Governments, as well as the project management of the Perumnas Parayasa, Parung Panjang for the assistance and permission given during this research.

\section{References}

1. A.E. Lucianto, H.S. Hasibuan, H. Herdiansyah, Sustainability Management of Green Neighborhood Index: Greenship GBCI in Subsidized Hosing (case Perumnas Parung Panjang, Indonesia), in Proceedings of the IBIMA Conference, 4-5 November 2020, Granada, Spain (2020)

2. A. Reith, M. Orova, Do Green Neighborhood ratings cover sustainability?. Ecol. Indic. 48, 660-672 (2014) https://doi.org/10.1016/j.ecolind.2014.09.005

3. A. Sharifi, A. Murayama, Neighborhood sustainability assessment in action: Crossevaluation of three assessment systems and their cases from the US, the UK, and Japan, Build Environ. 72, 243-258 (2014) https://doi.org/10.1016/j.buildenv.2013.11.006

4. BPS, Badan Pusat Statistik Digital Website (2020) https://www.bps.go.id/subject/12/kependudukan.html\#subjekViewTab3

5. BREEAM Communities, BREEAM Communities technical manual SD202 1.1 (2012) www.breeam.org

6. Green Building Council Indonesia, Greenship Neighborhood version 1.0 (2015) https://www.gbcindonesia.org/download/doc download/157-greenship-neighborhood$\underline{\text { ver-1-0 }}$

7. M. Orova, A. Reith, Multiscalarity in International Sustainable Assesment Systems: A Qualitative Comparison of LEED, CASBEE, BREEAM, DGNB and ESTIDAMA on Building Neighborhood and City Scale, IOP Conf. Ser.: Earth Environ. Sci. 290 (2019) https://doi.org/10.1088/1755-1315/290/1/012056

8. S. Baqutaya. F. Raji, Affordable Housing Policy: Issues and Challenges among MidlleIncome Groups. Int. J. Social. Scienc. Humanit. 6, 6 (2016) https://doi.org/10.7763/IJSSH.2016.V6.686

9. S.Z.H.S. Jamaludin, S.A. Mahayuddin, S.H.A. Hamid, Challenges of Integrating Affordable and Sustainable Housing in Malaysia. IOP Conf. Ser. Earth Environ. Sci. 140 (2018) https://doi.org/10.1088/1755-1315/140/1/012001

10. S. Karuppannan, A. Sivam, Sustainable Development and Housing Affordability. Australia: Institute of Sustainable Systems and Technologies, University of South Australia (2009) https://www.researchgate.net/publication/255606423

11. R. Rejoni, B. Sulistyana, I.S. Fatimah, Penerapan Sistem Perangkat Penilaian Pada Kawasan Perumahan, Studi Kasus Kawasan Perumahan di Kota Bogor, Indonesia. Jurnal Lanskap Indonesia, 8, 2 (2016) https://doi.org/10.29244/jli.2016.8.2.14-27

12. U.S. Green Building Council, LEED v4 for Neighborhood Development (2018) https://www.usgbc.org/leed/v41

13. V.W.Y. Tam, H. Karimipour, K.N. Le, J. Wang, Green Neighborhood: Review on the International Assessment Systems. Renewable and Sustainable Energy Reviews, 82, 689-699 (2108) http://doi.org/10.1016/j.rser.2017.09.083 